\title{
SOSIALISASI POTENSI AKUAPONIK DENGAN MEMANFAATKAN PEKARANGAN RUMAH MELALUI MEDIA SOSIAL
}

\section{Muhamad Imaddudin ${ }^{1)}$, Lin Eflina Nailufa ${ }^{2)}$, Aprilisa Risky Diana ${ }^{3)}$, Nur Indah ${ }^{4)}$, Ima Fitriana ${ }^{5)}$, Aufa Nuski Laila ${ }^{6}$, Muhammad Alaudin ${ }^{7)}$}

Program Studi Tadris IPA, Fakultas Tarbiyah, Institut Agama Islam Negeri Kudus

\begin{abstract}
Abstrak
Pekarangan merupakan area di sekitar rumah yang mudah diupayakan untuk memenuhi nutrisi mikro melalui perbaikan menu pangan dan perekonomian keluarga. Salah satu pemberdayaan masyarakat untuk optimalisasi lahan pekarangan dengan menciptakan usaha budidaya skala rumah tangga adalah melalui teknologi akuaponik. Akuaponik adalah gabungan sistem akuakultur dan hidroponik. Program pengabdian kepada masyarakat ini terdiri dari tiga tahapan utama yaitu (1) pembuatan sistem akuaponik pada pekarangan rumah warga; (2) pembuatan konten sosialisasi; (3) sosialisasi melalui media sosial. Dukungan media lainnya juga digunakan untuk trailer konten pada WhatsApp, laman Facebook, dan Instagram. Analisis dilaksanakan pada jumlah penayangan, durasi tonton rata-rata, jenis sumber akses media sosialiasi, perolehan like dan persentasenya, serta total komentar. Hasil menunjukkan retensi penonton sebanyak $31,0 \%$, perolehan $23,1 \%$ dari sumber eksternal diperoleh dari platform Whatsapp, prsentase like yang didapatkan mencapai 100\% dengan perolehan 51 like dan total komentar 18 komentar. Hal ini menunjukkan adanya potensi minat dari warganet untuk mengelola teknologi akuaponik. Respon dari warganet mencakup mulai dari kelebihan akuaponik, modal yang butuhkan, serta ingin membuat bisnis teknologi akuaponik akan tetapi terkendala lahan yang sempit.
\end{abstract}

Keywords: sosialisasi, akuaponik, pekarangan, media sosial.

\begin{abstract}
The yard is an area around the house that is easily pursued to increase the fulfillment of micronutrients by improving the food menu and the family economy. One of the community empowerments to optimize their yards by creating cultivation at a household scale is through aquaponics technology. Aquaponics is a combination of aquaculture and hydroponic systems. This activity consists of three main stages, namely (1) the creation of an aquaponic system in the residents' yards; (2) creating socialization content; (3) socialization through social media. Supports from other media are also used for content trailers, namely on WhatsApp, Facebook, and Instagram. The analysis was carried out on the number of views, average viewing duration, types of sources of social media access, acquisition of likes and percentage of likes, and total comments. The results show audience retention of $31.0 \%, 23.1 \%$ of external sources obtained from the Whatsapp platform, the percentage of likes obtained reached 100\% with 51 likes and a total of 18 comments. This shows the potential interest of netizens to manage aquaponics technology. The responses from netizens include starting from the advantages of aquaponics, the capital needed, and wanting to create an aquaponics technology business but are constrained by narrow land.
\end{abstract}

Keywords: socialization, aquaponics, yard, social media.

Correspondence author: Muhamad Imaduddin, imad@iainkudus.ac.id, Kudus, Indonesia 


\section{PENDAHULUAN}

Kondisi masyarakat di Indonesia dalam pembangunannya masih dirasakan belum merata. Hal ini membuat kondisi perekonomian masyarakatpun cukup beragam. Ketidakmerataan ini menuntut setiap kawasan harus mampu memberdayakan dirinya sendiri secara sosial dan ekonomi (Putri et al., 2010). Sebagian besar penduduk Indonesia berdomisili di daerah pedesaan dan hanya sebagian kecil yang bertempat tinggal di area perkotaan. Hal ini menunjukkan bahwa negara Indonesia merupakan negara agraris. Kehidupan masyarakat agraris bergantung pada penggunaan lahan sebagai sarana produksi pokok dan mayoritas bermata pencaharian sebagai petani (Basrowi \& Juariyah, 2010). Secara umum area perdesaan dicirikan dengan adanya struktur kegiatan kelompok masyarakat yang berbasis pertanian dan kondisi kepadatan penduduk yang lebih rendah dibanding kepadatan penduduk perkotaan. Dengan demikian, kondisi lahan pekarangan pedesaan lebih renggang dari pada lahan perkotaan dan cara hidup serta pola budaya masyarakat lebih memanfaatkan sumber daya alam yang ada di sekitarnya (Suparmini, 2007).

Pekarangan merupakan area di sekitar rumah yang mudah diupayakan untuk meningkatkan pemenuhan nutrisi mikro melalui perbaikan menu pangan dan perekonomian keluarga (Oktaviani et al., 2020; Pujiati et al., 2018). Pekarangan ini juga disebut lumbung hidup atau apotek hidup. Meskipun demikian, lahan pekarangan pedesaan belum dapat dimanfaatkan secara optimal. Lahan produktif yang seharusnya masih bisa untuk dilakukan kegiatan pertanian belum teroptimalkan. Sejalan dengan perkembangan teknologi, penduduk mulai mencari solusi agar lahan pekarangan yang kurang dioptimalkan menjadi suatu usaha yang mampu menunjang perekonomian. Salah satu upayanya adalah pengelolaan secara berkelompok untuk pemeliharaan lahan produktif pekarangan serta pemanenan hasil. Bentuk pengelolaan pekarangan dapat dilakukan dengan menjalankan usaha budidaya, contoh budidaya ikan dan tanaman yang mudah dipelihara dengan fasilitas yang minim. Salah satu pemberdayaan masyarakat yang sudah dikerjakan yaitu melalui pelaksanaan optimalisasi lahan pekarangan dengan menciptakan usaha budidaya dalam skala rumah tangga (Putri et al., 2010). Bentuk pemberdayaan tersebut salah satunya adalah dengan implementasi sistem akuaponik pada pekarangan rumah.

Akuaponik adalah gabungan sistem akuakultur dan hidroponik yang saling menguntungkan (Wiguna, 2015). Akuakultur merupakan budidaya ikan, sedangkan hidroponik dapat diartikan memberdayakan air. Pemeliharaan ikan dalam satu wadah dapat menyebabkan kondisi air yang ada memiliki kadar amonia yang pekat sehingga berpotensi untuk meracuni ikan. Dengan adanya penggabungan sistem akuakultur dengan sistem hidroponik, amonia dalam limbah perikanan dapat berpeluang untuk ditransformasikan menjadi nitrit dan nitrat oleh mikroba yang ada pada media sistem hidroponik. Senyawa yang ditransformasi dapat dimanfaatkan oleh tanaman untuk tumbuh kembangnya (Maharani \& Sari, 2016). Sistem akuaponik sebagai sumber pupuk organik yang baik bagi pertumbuhan tanaman dengan memanfaatkan kotoran ikan (Putra et al., 2013). Teknologi akuaponik juga dapat dijadikan pilihan dalam upaya memecahkan permasalahan terbatasnya ketersediaan air (Putra et al., 2013). Produk yang dihasilkan merupakan produk organik karena mengoptimalkan pemanfaatan pupuk dari kotoran ikan yang telah melalui proses biologis. Keuntungan nyata dari sistem ini adalah dihasilkannya dua produk sekaligus; yaitu sayur dan ikan, dari satu unit produksi. 
Tahun 2020 merupakan tahun yang berbeda dari tahun-tahun sebelumnya. Mulai bulan maret 2020, virus covid-19 telah menyebar hampir diseluruh dunia, tidak terkecuali di Indonesia. Virus ini perlahan menjadi pandemi global yang belum diketahui pasti kapan bisa berakhir. Untuk itu mengharuskan semua masyarakat melakukan aktivitas secara online baik pada sektor pendidikan maupun aktivitas pekerjaan. Dengan demikian, dampak virus ini pun merambat pada sektor ekonomi maupun sosial. Salah satu pergeseran aktivitas masyarakat adalah mulai banyak dilaksanakannya aktivitas berbasis daring dengan memanfaatkan ragam media sosial. Media sosial, salah satunya YoeTube, dapat menjadi sumber dan media pembelajaran yang dapat dimanfaatkan dengan baik pada kondisi pandemi Covid-19 ini. YouTube meningkatkan minat dan mendukung gaya belajar generasi digital. YouTube memberikan pengalaman pembelajaran dengan teknologi yang baru yang akan berguna dalam jangka waktu yang panjang, selain itu YouTube juga menyediakan jutaan video dengan berbagai ragam topik atau materi yang bisa diintegrasikan dalam pembelajaran dan menjadi perpustakaan video gratis yang sangat luas bagi masyarakat sehingga mereka dapat belajar secara mandiri (Lestari, 2017).

Sejalan dengan pelaksanaan pengabdian kepada masyarakat di era pandemi saat ini, sosialisasi teknologi akuaponik dalam budidaya ikan yaitu untuk memberikan informasi aktivitas dan peluang usaha kepada masyarakat di masa pandemi dengan menggunakan sistem media sosial yaitu melalui fitur YouTube, Facebook, Instagram, serta menganalisis hasil respon masyarakat dari konten teknologi akuaponik tersebut.

\section{METODE PELAKSANAAN}

Kegiatan pengabdian kepada masyarakat ini terdiri dari tiga tahapan utama yaitu (1) pembuatan sistem akuaponik pada pekarangan rumah warga; (2) pembuatan konten sosialisasi; (3) sosialisasi melalui media sosial. Pembuatan sistem akuaponik terdiri dari tiga aktivitas utama yaitu (1) penanaman bibit dan pembuatan kolam (07 Juli 2020); (2) Pemasangan sistem akuaponik (13 Juli 2020); (3) Pemanenan sayur (03 Agustus 2020). Serangkaian kegiatan pada tahapan pertama tersebut didokumentasikan serta dilakukan pengeditan untuk pembuatan konten sosialisasi. Kegiatan dilaksanakan di Desa Gulang RT 05 RW 02 Mejobo Kudus.

Pengunggahan konten dilaksanakan pada laman YouTube Channel "Tadris IPA IAIN Kudus" (https://www.YouTube.com/c/TadrisIPAIAINKudus) pada tanggal 05 Agustus 2020. Dukungan media lainnya juga digunakan untuk trailer konten pada WhatsApp, laman Facebook (KKN Tadris IPA IAIN Kudus \& Kkn Iainkudus Tujuhdelapan) dan Instagram (Official_kkntadrisipa \& kkn_ik_dr_tipa78). Analisis utama menggunakan laman YouTube Studio (https://studio.YouTube.com/channel/UCK0YJHM4cLLlyohkMheYFzg). Analisis dilaksanakan pada jumlah penayangan, durasi tonton rata-rata, jenis sumber akses media sosialiasi, perolehan like dan persentasenya, serta total komentar.

\section{HASIL DAN PEMBAHASAN}

Sosialisasi melalui internet sudah mulai dikembangkan. Penggunaan media internet semakin hari semakin banyak. Menurut Hootsuite dan We Are Social, 88 persen dari semua pengguna internet Indonesia - sekitar 132 juta orang - aktif menggunakan 
YouTube. Penelitian lain menunjukkan bahwa rata-rata hingga 47 persen orang Indonesia mengakses YouTube setiap hari selama sekitar 30 menit. Adapun 53 persen orang Indonesia menggunakan YouTube untuk mencari informasi produk, dan 86 persen orang Indonesia menggunakannya untuk memahami cara menggunakan produk (Greenhouse, 2020). Penelitian mengenai Computer Mediated Communication (CMC) telah menciptakan konsep baru dalam interkasi sosial sebagaimana yang telah dikaji pada aspek sosiologis ataupun politis (Widarini, 2019).

Pada program sosialisasi ini, konten yang diunggah pada media sosial menjadi suatu bentuk interaksi antara kreator atau pihak yang mensosialisasikan serta dengan warganet yang menjadi masyarakat sasaran. Ditinjau dari tahapan pelaksanaannya maka dapat diketahui rangkaian kegiatan pada proses pengabdian kepada masyarakat ini.

\section{Pembuatan Sistem Akuaponik Pada Pekarangan Rumah Warga}

Modal awal untuk membuat media akuaponik jika menggunakan bahan-bahan baru memang cukup banyak, meskipun demikian hal itu dapat dihindari jika menggunakan barang-barang bekas yang masih layak pakai. Panen bisnis teknologi akuaponik sebagai contoh kangkung, dapat dipanen minimal 25 hari sejak pembenihan, sedangkan ikan lele dapat dipanen minimal 3-4 bulan. Adapun manfaat akuaponik untuk kolam dan ikan adalah kondiri air kolam tetap terjaga kebersihannya, air kolam tidak terkontaminasi zat-zat yang berbahaya bagi ikan karena telah melalui proses penyaringan atau filtrasi (Maharani \& Sari, 2016). Peluang bisnis akuaponik juga tidak harus membutuhkan lahan yang luas karena hanya membutuhkan bak dan penempatan tanaman sayur pada satu lokasi bertingkat.

Prinsip kerja akuaponik adalah air kolam dialirkan menuju talang-talang air yang sudah dilengkapi dengan media tanam serta bibit tanaman untuk proses pengolahan air kolam, serta dilanjutkan dengan mengalirkannya kembali ke dalam kolam ikan. Agregat tanah liat, batu kerikil, dan serpihan karet busa dapat dijadikan media tanam. Media tanam berupa lembaran, tidak terdekomposisi, tidak menyebabkan perubahan komposisi kimia air, dan tidak mengeluarkan senyawa toksik bagi tanaman serta bakteri nutritif (Maharani \& Sari, 2016). Media tanam yang digunakan dalam pengabdian kepada masyarakat ini berupa serpihan genting dan arang. Bibit tanaman yang digunakan untuk akuaponik adalah tanaman kangkung.

Pada program pengabdian ini, sistem resirkulasi yang dipakai adalah resirkulasi terbuka, dan sistem akuaponik yang digunakan adalah sistem rakit apung dengan pipa PVC. Tanaman tidak perlu dipupuk untuk menunjang kesuburan dan pertumbuhan. Hal ini dikarenakan limbah kolam ikan yang berupa kotoran dan sisa pakan mengandung unsur makro dan mikro yang dibutuhkan tanaman. Selain itu, proses penyiraman tidak perlu dilakukan secara manual karena air kolam dipompa ke atas hingga mampu memenuhi kebutuhan air pada tanaman.

Rincian pada tahapan ini terdari proses rancang bangun sistem akuaponik di pekarangan rumah dengan rincian langkah kerja sebagaimana ditampilkan pada Tabel 1. 
Tabel 1. Langkah Kerja Penyusunan Sistem Akuaponik pada Pekarangan Rumah

\begin{tabular}{|c|c|c|}
\hline No. & Langkah Kerja & Keterangan Gambar \\
\hline 1. & $\begin{array}{l}\text { Pada proses pembuatan kolam, terpal dilengkapi para- } \\
\text { para dari kayu yang dipasang dengan ketinggian tepat } \\
\text { diatas permukaan kolam terpal dan tandon. }\end{array}$ & \\
\hline 2. & $\begin{array}{l}\text { Pemasangan pompa dan pipa sirkulasi air: } \\
\text { Pipa yang berada di atas tanaman yang merupakan pipa } \\
\text { berisi air hisapan dari kolam yang akan dialirkan ke } \\
\text { tanaman. } \\
\text { Pipa yang berada di bawah tanaman merupakan pipa } \\
\text { berisi air dari tanaman yang dialirkan ke tandon sebelum } \\
\text { mengalir kembali ke kolam. }\end{array}$ & \\
\hline 3. & $\begin{array}{l}\text { Pemasangan selang di antara tanaman dan pipa bawah } \\
\text { presirkulasi awal air (kurang lebih selama seminggu). }\end{array}$ & \\
\hline
\end{tabular}

4. $\quad$ Pipa paralon yang diberi lubang diatasnya yang sesuai dengan ukuran wadah tanamannya untuk memposisikan tanaman.

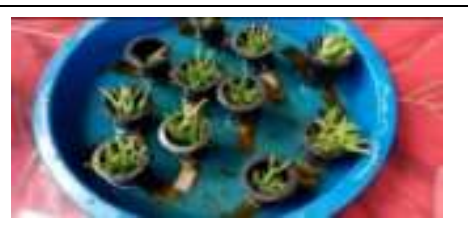

5. Setelah tanaman dimasukan kedalam pipa, pada kolam dipasangkan pompa aquarium. Pompa dari selang aquarium dimasukkan ke dalam paralon sehingga air kolam ikan mengalir ke dalam paralon dan kembali ke kolam lagi.

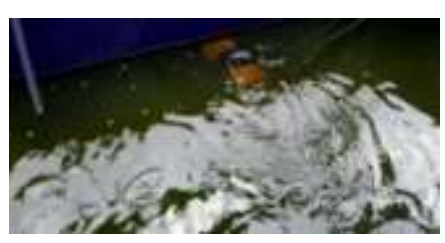

\section{Pembuatan Konten Sosialisasi Sistem Akuaponik}

Pembuatan konten sosialisasi dilakukan dengan mendokumentasikan langkahlangkah pada tahapan perakitan sistem dan proses pemanenan. Selain itu disiapkan thumbnail yang difungsikan sebagai media informatif terkait dengan teknologi akuaponik yang memiliki banyak manfaat. Hal ini diperlihatkan pada Gambar 1.

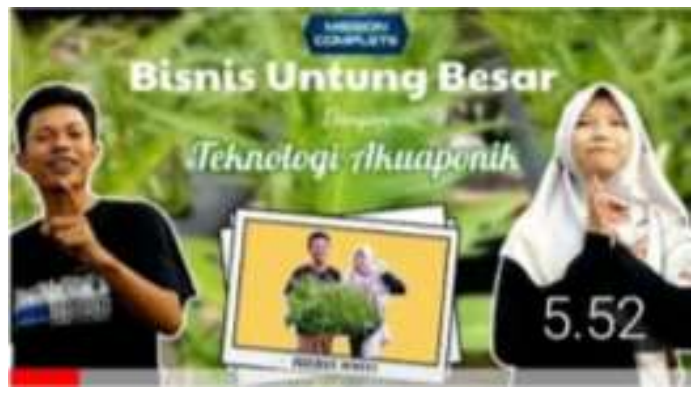

Gambar 1. Konten Video 

yaitu:

Konten singkat dibuat dengan durasi 5:51 menit yang terdiri dari tiga bagian

1. Pembuka

Pada bagian pembuka ini dijelaskan situasi akan dilaksanakan panen tanaman kangkung hasil dari sistem akuaponik dan berpotensi untuk dikomersilkan.

2. Inti

Bagian ini menjelaskan sistem akuaponik dan tahapan perancangan, serta proses pemeliharaannya.

3. Penutup

Bagian ini memberikan simpulan terkait dengan manfaat dan kelebihan system akuaponik sehingga dapat meyakinkan penonton tayangan video.

\section{Sosialisasi Sistem A kuaponik pada Media Sosial}

Sosialisasi dilakukan melalui media sosial dilaksanakan melalui laman YouTube https://youtu.be/MUpds90d6HI dan judul utama yaitu "Teknologi Akuaponik Dalam Budidaya Ikan". Konten dipromosikan menggunakan media WhatsApp, Facebook dan IG. Analisis pada YouTube Studio menunjukkan durasi rata-rata tayangan atau retensi sebesar 31,0\%. Analisis dilaksanakan pada tanggal 05 Agustus - 05 September 2020. Hasil analisis sebagaimana diperlihatkan pada Gambar 2.

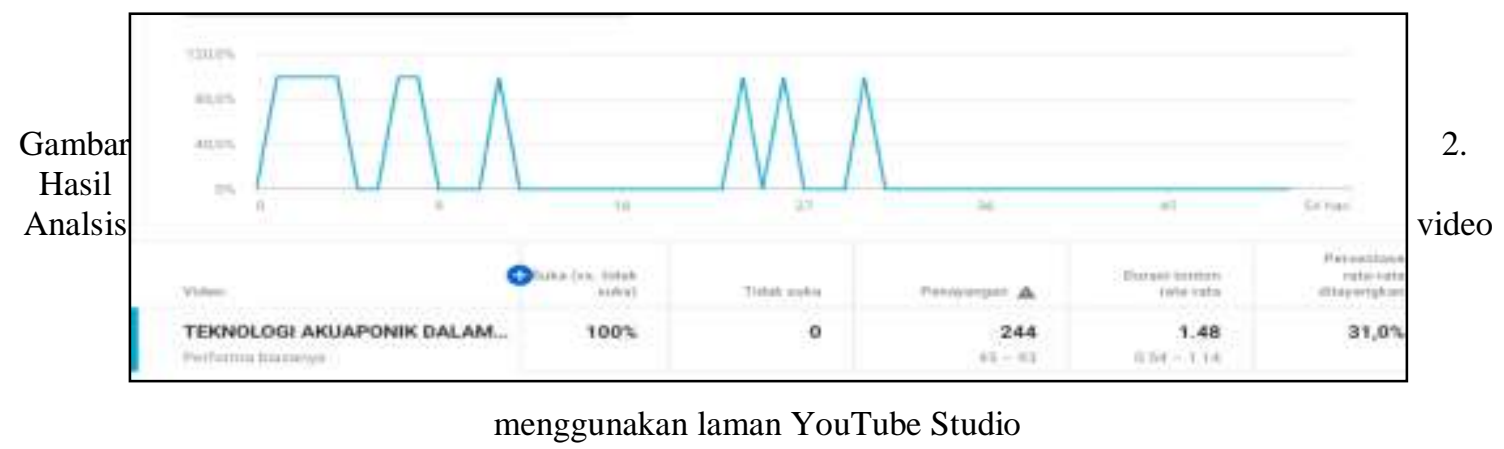

Perolehan viewers berasal dari berbagai jenis sumber. Jika dipersentasekan perolehan $35,8 \%$ dari halaman channel, 23,1\% dari sumber eksternal, 14,0\% dari penulusuran youtube, $10,7 \%$ dari fitur youtube lainnya, dan 6,2\% dari halaman playlist, lalu sisanya 10,3\% dari sumber lainnya. Hal ini sebagaimana terlihat pada Gambar 3.
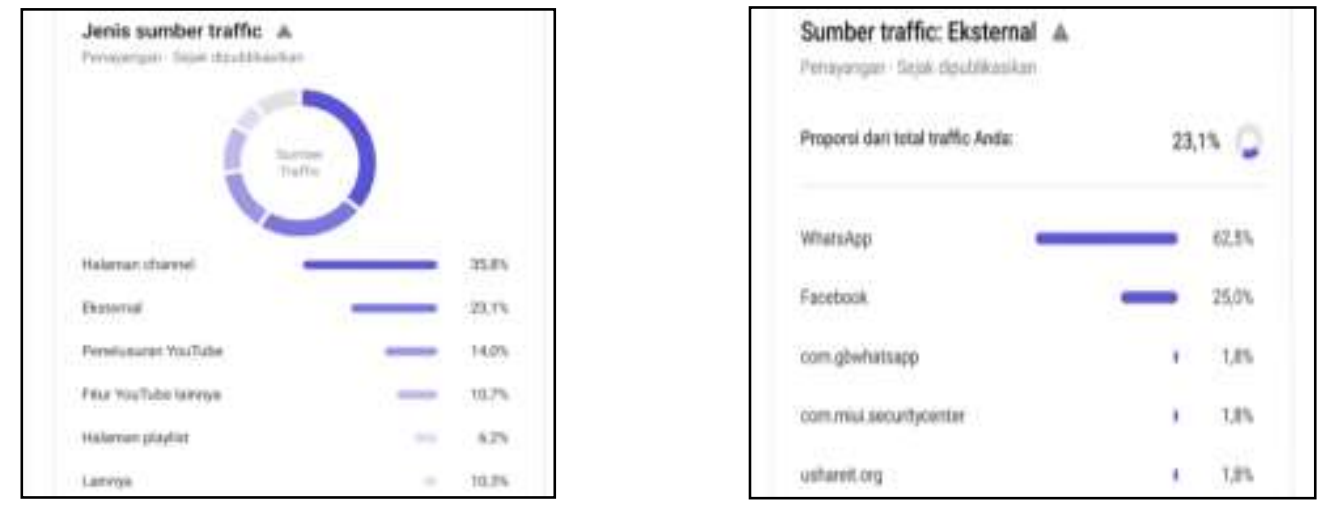

Gambar 3. Jenis dan sumber traffic perolehan viewer 
Perolehan 23,1\% dari sumber eksternal diperoleh dari platform Whatsapp di urutan teratas yang berarti banyaknya penonton yang mendapatkan info melalui platform tersebut sebesar $62,5 \%$, dari platform Facebook sebesar $25 \%$ dan sisanya $1,8 \%$ dari com.gbwhatsapp, com.miui.securitycenter dan ushareit.org. Persentase like yang didapatkan mencapai $100 \%$ dengan perolehan 51 like dan total komentar 18 komentar. Beberapa respon penonton ditunjukkan pada Gambar 4.

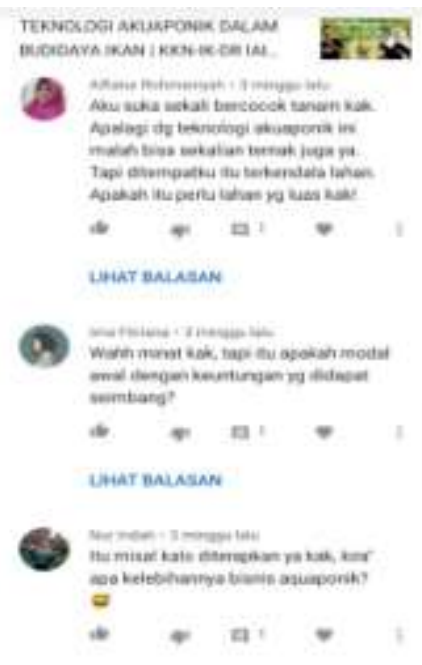

Gambar 4. Beberapa komentar yang diberikan oleh warganet

Strategi sosialisasi yang dilakukan yaitu dengan memanfaatkan fitur yang ada di youtube melalui teknologi akuaponik mendapat banyak respon dari warganet. Pertanyaan-pertanyaan termuat pada kolom komentar. Hal ini menunjukkan adanya potensi minat dari warganet untuk mengelola teknologi akuaponik. Respon dari warganet mencakup mulai dari kelebihan akuaponik, modal yang butuhkan, serta ingin membuat bisnis teknologi akuaponik akan tetapi terkendala lahan yang sempit.

Berpedoman pada teori Computer Mediated Communication (CMC), kegiatan yang dilaksanakan merupakan bentuk komunikasi yang menggunakan perantara berupa perangkat teknologi. Interaksi CMC ini memiliki karakteristik yang berbeda dengan komunikasi tatap muka yaitu tidak dapat diperolehnya umpan balik secara reguler, minimnya tanda-tanda interaksi sosial, serta munculnya kelompok sosial yang tidak dikenal (Widarini, 2019). Interaksi hanya dilakukan dengan memberikan respon like atau dislike, serta komentar berupa teks maupun emoticon. Karakteristik dalam interaksi melalui CMC ini menuntut kemampuan dan keterampilan personal pengguna YouTube (Morreale et al., 2012). Internet dalam hal ini adalah YouTube telah muncul sebagai media komunikasi baru (new media) untuk memudahkan pola komunikasi antara individu dengan individu lain atau satu kelompok dengan bagian dari kelompoknya maupun kelompok lain (Faiqah et al., 2016; Priana, 2017). Selain dimanfaatkan sebagai media komunikasi, internet termasuk YouTube juga digunakan untuk media penyampaian informasi publik maupun sebagi perpustakaan publik yang tidak dibatasi ruang dan waktu (Priana, 2017).

Pemanfaatan YouTube sebagai media penyebaran informasi terkait dengan sistem akuaponik dapat memberi efek yang mencakup efek kognitif, afektif, integrasi pribadi 
serta efek berkhayal (Akbar, 2018). Efek kognitif ini berkaitan dengan munculnya pemahaman informasi implementasi sistem akuaponik, serta manfaatnya. Efek afektif mencakup perasaan warganet saat menonton tayangan video YouTube berkaitan dengan sistem akuaponik. Efek integrasi pribadi berkaitan kesesuaian kebutuhan pribadinya atau diri sendiri dengan informasi yang diberikan oleh video konten program ini. Efek integrasi sosial yang timbul karena adanya keterkaitan informasi dengan kondisi teman, keluarga, tetangga sekitar, ataupun masyarakat sekitarnya. Efek berkhayal berkaitan dengan hiburan ataupun imajinasi ataupun impian yang diperoleh pada saat dan setelah menonton tayangan.

Didasarkan pada apa yang telah dilakukan, sosialisasi ini memang masih sangat terbatas dan dilaksanakan dengan sistem daring, Hal ini mengingat program pengabdian masyarakat ini merupakan aktivitas yang coba disesuaikan dengan situas dan kondisi yang masih sangat tidak memungkinkan untuk mengumpulkan massa masyarakat secara langsung, Meskipun demikian, kebermaknaan program ini dapat terungkap dari kondisi analisis video kontan yang telah diunggah pada laman YouTube.

\section{SIMPULAN}

Sosialisasi yang telah dilaksanakan berkaitan dengan teknologi akuaponik memberikan informasi kepada masyarakat melalui media internet. Informasi yang diberikan berkaitan dengan pemanfaatan pekarangan atau lahan yang ada dirumah untuk aktivitas pertanian organik yang multifungsi. Hasil dari respon dan tayangan dan komentar dianalisis untuk menunjukkan seberapa jauh konten program yang dilaksanakan bermanfaat bagi masyarakat. Kondisi ini merupakan upaya untuk mengoptimalkan aktivitas pengabdian di masa pandemi covid-19 dengan memanfaatkan media sosial YouTube sebagai sarananya. Di masa mendatang, sosialisasi secara luring diperlukan untuk memberikan alternatif bisnis bagi masyarakat terutama masyarakat pedesaan yang masih memiliki lahan produktif.

\section{DAFTAR PUSTAKA}

Akbar, A. (2018). Efektifitas Youtube sebagai Media Penyebaran Informasi (Studi pada Serambi on TV). Universitas Islam Negeri Ar-raniry.

Basrowi, B., \& Juariyah, S. (2010). Analisis Kondisi Sosial Ekonomi dan Tingkat Pendidikan Masyarakat Desa Srigading, Kecamatan Labuhan Maringgai, Kabupaten Lampung Timur. Jurnal Ekonomi \& Pendidikan, 7(1), 58-81.

Faiqah, F., Nadjib, M., \& Amir, A. S. (2016). Youtube sebagai sarana komunikasi bagi komunitas makassarvidgram. Jurnal Komunikasi KAREBA, 5(2), 259-272.

Greenhouse. (2020). Indonesia's Social Media Landscape: An Overview. https://greenhouse.co/blog/indonesias-social-media-landscape-an-overview/

Lestari, R. (2017). Pengunaan Youtube sebagai Media Pembelajaran Bahasa Inggris. Seminar Nasional Kedua Pendidikan Berkemajuan Dan Menggembirakan (The Second Progressive and Fun Education Seminar), 607-612.

Maharani, N. A., \& Sari, P. N. (2016). Penerapan Aquaponic Sebagai Teknologi Tepat Guna Pengolahan Limbah Cair Kolam Ikan di Dusun Kergan, Tirtomulyo, 
Kretek, Bantul, Yogyakarta. Jurnal Pengabdian Kepada Masyarakat (Indonesian Journal of Community Engagement), 1(2), 172-182. https://doi.org/10.22146/jpkm.10603

Morreale, S. P., Spitzberg, B. H., \& Barge, J. K. (2012). Human communication: Motivation, knowledge and skills (Second, Vol. 53, Issue 9). Thomson Learning. https://doi.org/10.1017/CBO9781107415324.004

Oktaviani, A. D., Ulayyah, N. N. P., Yuliani, T. S., Rahayu, M. S., Lubis, I., \& Nurul, F. (2020). Pemanfaatan Lahan Pekarangan untuk Memenuhi Kebutuhan Keluarga di Desa Cintalaksana, Kecamatan Tegalwaru, Kabupaten Karawang. Jurnal Pusat Inovasi Masyarakat, 2(4), 535-539.

Priana, R. Y. S. (2017). Pemanfaatan Vlog sebagai Media Pembelajaran Terintegrasi Tekhnologi Informasi. Prosiding Seminar Nasional Pendidikan FKIP UNTIRTA 2017, 313-316.

Pujiati, A., Megawanti, P., \& Retariandalas, R. (2018). Pemberdayaan Ibu Rumah Tangga melalui Pelatihan (3M) Meningkatkan Kesejahteraan Keluarga. Jurnal PkM: Pengabdian Kepada Masyarakat, 1(1), 28-31. https://doi.org/10.30998/jurnalpkm.v1i01.2145

Putra, I., Mulyadi, M., Pamukas, N. A., \& Rusliadi, R. (2013). Peningkatan Kapasitas Produksi Akuakultur pada Pemeliharaan Ikan Selais (Ompok Sp) Sistem Aquaponik. Jurnal Perikanan Dan Kelautan, 18(1), 1-10. file:///C:/Users/youhe/Downloads/kdoc_o_00042_01.pdf

Putri, H. M., Asnawi, A., \& Hikmayani, Y. (2010). Pemanfaatan Lahan Pekarangan sebagai Bentuk Pemberdayaan Sosial Ekonomi Masyarakat melalui Usaha Budidaya Lele (Studi Kasus di Desa Salamredjo Kecamatan Sentolo, Kulon Progo, DIY). J. Bijak Dan Riset Sosek KP, 5(2), 159-167.

Suparmini, S. (2007). Keterkaitan Desa-Kota: Sebagai Alternatif Pembangunan Perdesaan. Geomedia: Majalah Ilmiah Dan Informasi Kegeografian, 5(2), 193206. https://doi.org/10.21831/gm.v5i2.14192

Widarini, D. A. (2019). Pemanfaatan Media Sosial dalam Sosialisasi Kesehatan Reproduksi dan Nutrisi Untuk Perempuan. Jurnal Komunikasi Pembangunan, 17(1), 92-101.

Wiguna, I. (2015). Panen Ganda Aquaponic. Trubus 549. Edisi Agustus 2015/ XLVI:11-19. 